\title{
PENSION FUND CAPITALISM: A CAUSAL ANALYSIS
}

\author{
Gordon L Clark, School of Geography, University of Oxford \\ Mansfield Rd., Oxford OX1 3TB, United Kingdom \\ gordon.clark@geog.ox.ac.uk (draft 15th December 1997)
}

ABSTRACT. Since 1980, UK individual pension and retirement assets have increased about 10 fold to about $£ 1.1$ trillion. Over the same time, US household retirement assets have increased about 7 fold to more than $\$ 5$ trillion. High rates of asset growth have also been observed for Australia and Canada. Notwithstanding their current high standards of living, much of continental Europe has not shared in these extraordinary rates of growth of pension assets. In fact, many analysts believe that their long term prosperity is threatened (relatively speaking) by inefficient, institutionally cumbersome finance sectors. While saving now for retirement has significant advantages for beneficiaries, less important is the fact that the growth of pension assets in the AngloAmerican economies have profoundly changed the financial structure of these countries. Here I explain how and why pension assets have grown so large in the Anglo-American countries, beginning with an historical account to identify the reasons why German and continental European countries excluding The Netherlands and Switzerland have not shared the same rates of growth of pension assets. In doing so, the paper develops an explanatory model which discriminates between various causes of Anglo-American pension fund capitalism: structural determinants (institutional framework), second-order determinants (post-war conditions), and third-order determinants (contributions). The identified causal logic relies upon Ehring's conception of causality, integrating structure with historical and geographical contingency. Implications are also drawn regarding the significance of AngloAmerican pension funds for global capitalism.

ACNOWLEDGEMENTS. This paper was prepared for the Annual Meeting of the Association of American Geographers, March 1998. It was made possible by the support of Professor Michael Berry, Executive Director of the Australian Housing and Urban Research Institute. Melanie Feakins and Leslie Turano provided research assistance, Roy Goode, Risto Laulujainen, Colin Mayer, Olivia Mitchell, Stephanie Palmer, and Martin Purves helped with sources, Amanda Root provided a timely reference to historiography, Jan Adams and Julie Kast (Greenwich Associates) provided data and Jan Magee processed the manuscript. None of the above should be held responsible for any errors or omissions. 


\section{Introduction}

Pension funds are very important financial institutions in Anglo-American economies. They dominate national and international securities' markets. They are a force to be reckoned with when governments seek to manage interest rates currency exchange rates. And they are an increasingly powerful voice in corporate governance and domestic public policy. Just thirty years ago pension assets were relatively modest compared to individuals' savings deposits, and just twenty years ago large pension funds tended to be sleepy institutions commonly equated with insurance companies rather than the global finance companies many have come to emulate. Simple statistics are compelling. In the UK, from 1980 to 1996 personal pension assets grew ten-fold to be worth more than $£ 1.1$ trillion; in the US over the same period, household retirement assets grew by a factor of seven being now worth more than $\$ 5$ trillion, and in Australia with the introduction of mandatory contributions, pension fund assets are projected to double by 2010 .

The rise and significance of pension funds has been described in various ways. Drucker (1979) thought that their growth presaged an era of "pension fund socialism": because pension plans own large tranches of corporate equities workers now own the means of production by virtue of their status as the beneficiaries of pension plans. This is an intriguing idea, one that re-appears every so often in debates about the proper scope pension fund investments. But the idea of "pension fund socialism" is really an exercise in political rhetoric rather than reality. Pension funds depend upon the performance of national and international markets for their accumulated wealth. Their assets are the product of the employment relation, and agency relationships in the investment management industry. The concentration of financial assets in pension funds coupled with the fact that trustees and their investment advisors have considerable autonomy from plan beneficiaries matches in substance the separation of ownership from control characteristic of modern corporations. Plan beneficiaries are more like stockholders than owners, albeit with even less clout than individual stockholders. In this respect, pension fund capitalism is a further stage in the evolution of capitalism rather than a profound break with the past (see Minns 1980 on the UK and Robert Clark 1981 on the US). ${ }^{\text {i }}$ 
Not all advanced economies are equal partners in pension fund capitalism. It is principally an Anglo-American phenomenon. The three largest European economies France, Germany and Italy have weak, even non-existent (Italy) pension fund sectors; the value of their pension fund assets are low relative to other much smaller countries like The Netherlands and Switzerland and the values of those assets relative to GDP are modest except when compared to Belgium and Portugal. ${ }^{\mathrm{ii}}$ By all accounts, the German, French and Italian economies have few important indigenous market-based investment management firms. Their pension assets are trivial in relation to the AngloAmerican economies, and there are very few pension funds in these economies that could rival the size and growth potential of the larger Anglo-American funds. Inevitably, the rate of market-based financial innovation is very different between these types of economies. At the same time, there can be little doubt that the burgeoning growth of Anglo-American pension assets has had, and will have in the future, significant implications for the global economy.

While many countries have employer-sponsored pension systems operating in parallel with state-funded retirement systems, the growth and significance of pension assets in the Anglo-American countries is a qualitatively different process compared to most continental countries. Indeed so distinctive is the Anglo-American experience that some developing countries and the transitional economies of eastern Europe have sought to emulate the institutional structure and design of Anglo-American systems rather than other continental systems. Even in countries long dominated by the German financial model of state-funded social security and integrated banking and corporate relations, questions have been raised about the future of this model in the face of the burgeoning financial assets of the Anglo-American pension driven economies. Likewise, there have been proposals in the Anglo-American economies to privatise state security systems or supplement systems with private contributions to take advantage of the perceived virtues of the pension and institutional investment management industry (see Mitchell and Zeldes 1996 on the prospects for privatising US social security and Clark et al. 1996 on the Australian system of compulsory pension contributions). ${ }^{\text {iii }}$

Why have pension funds become so important in the Anglo-American economies? What are the causes of pension fund capitalism? And what distinguishes the Anglo-American economies from continental economies (and especially Germany) 
in this regard? These three questions go to the heart of the paper. It introduces the reader to the world of pension fund capitalism, its history and causes. The paper begins with a brief history of pension fund capitalism and moves on to consider the issue of spatial heterogeneity -- the putative persistence of different economic systems like the German and continental economies excluding The Netherlands and Switzerland compared to the Anglo-American economies. This is the basis for a discussion of the causes of pension fund capitalism. While this paper is concerned with national and international comparisons, a spatial perspective quite different than that of Martin and Minns (1995) who are similarly interested in the geography of pension fund capitalism, it should be apparent that spatial differentiation is one of the building blocks underpinning this paper. In any event, I would argue that understanding the causal logic of which has created and sustained gross differences between financial systems is a necessary research project for all social sciences including geography.

\section{A Brief Historical Perspective}

State-funded pay-as-you-go (PAYG) social security pensions have been very important in Germany, France and Italy over much of the twentieth century. The close relationships between corporations and banks in Germany are another important difference between the Anglo-American market-based financial systems and the financial structures of continental Europe (see Roe 1994). And yet, invoking these types of differences is an ad hoc, partial, and even circular explanation of the differences between the major financial systems of the global economy. In any event, notwithstanding the significance of state-funded retirement pensions for German workers, many workers participate in employer-sponsored pension plans. German coverage rates are not so different from UK and US being between 45 and 50 percent. $^{\text {iv }}$ So what has caused the extraordinary growth of pension fund assets in the Anglo-American world? And what is distinctive about that experience? To answer these questions requires some history, informed by Roy Goode's (1993) report Pension Law Reform. This is followed with an analysis of causality.

As far as we know, the first mention of "pension" in English statute is to be found in 1285 (Ed I. St 4). There it was simply noted that if a prelate of the church were to demand a pension, all such demands were to be made in a special court (paraphrasing the early English). It is not known how such a court would have been 
constituted, nor do we know how a court would have dealt with such a demand. By the seventeenth century, it was well-established that the Crown would reward and compensate soldiers and sailors or their widows and orphans with a pension for service to the Crown. Eligibility was determined by military service, by physical disability (loss of limbs etc.), by financial ruin or by death. A 1662 statute (14. Cha. 2) provided for weekly payments to be administered at the local level. By the conclusion of the war with France, Parliament had voted life-time annuities not only for military service but also for help in raising the money necessary to sustain the war $(6 \& 7$. Will 3. Ch. V, 1694). Such pensions were to be paid by levies on excise taxes and the like. A century later, Parliament was also voting individuals ex gratia pensions. For example, in 1790 Parliament voted, on behalf of the Crown, Rev Francis Willis (a physician) an annuity of $£ 1000$ per year clear of any "deductions whatsoever" (30. Geo. 3. Ch. 44). These pensions were paid at the end of an individual's service to the government and/or the Crown at the discretion of their employer. Ex gratia pensions were a form of patronage.

As early as 1793, Parliament used its powers to promote friendly societies whose purpose it was to provide for members' "mutual relief and maintenance" in case of sickness, old age and infirmity (33. Geo. 3. Ch. 54). The purpose of such statutes was to encourage private provision for retirement (and infirmity) given that people were living longer. A Report of the House of Commons in 1827 on friendly societies noted that the available data suggested one half of all people alive at 25 years would live to 65 years, and more than one-third of those alive at 65 would live through to 80 years of age (p. 5). Throughout much of the nineteenth century, governments sought to encourage the growth and development of friendly societies by regulating their organisation, the role and responsibilities of trustees, and the financial security of contributors' assets (see 59. Geo. 3. Ch. 128, 1819 and 18 \& 19 Vict. Ch. 63, 1855). Over the century, coincident developments in the common law of trusts including judicial determinations concerning fiduciary duty were incorporated into the regulation of friendly societies (see Phillips 1957). While of limited significance in terms of their total membership, the promotion of friendly societies reflected governments' interests in focusing the financial burden of old age on individuals, and an ideological commitment to voluntary action (see Blake 1995). 
With respect to its own employees, through much of the nineteenth century UK governments provided superannuation schemes for significant groups of the civil service. In 1809 (49. Geo. 3. Ch. 96, an act was passed providing excise (tax) officers a superannuation scheme, reputedly one of the first of its kind in England although a limited scheme had been proposed for customs in 1686. Whereas governments had previously allocated pensions as compensation for military service and had provided select individuals ex gratia pensions, the excise officers' superannuation scheme was designed to sustain the administrative efficiency of the revenue collection process. Many excise officers held their positions for life. Others paid a weekly levy for the retirement of their predecessors, and some officers and their local authorities levied extra charges to pay for the retirement of the frail and infirm. The 1857 Report on the Operation of the Superannuation Act noted these ad hoc arrangements had been both objectionable and unsustainable. Thus, the 1809 act provided a means whereby excise officers could routinely retire by reason of age or infirmity, having been "rendered incapable of executing or performing their duty." The act specified eligibility criteria, benefit levels, and investment guidelines for the Commissioners of Excise. It became the model for many public and private superannuation schemes through the nineteenth and twentieth centuries.

However important this scheme was for the design of modern superannuation schemes, it was not immediately applied to all civil servants. In fact, by 1821 it had become apparent that the scheme was a significant financial burden on government revenue. A series of reforms followed tightening-up eligibility, limiting benefits according to years of service, introducing standards of employee performance, requiring participants to make their own contributions (salary deductions) and limiting the portability of pension contributions if excise officers were to leave their jobs. By the passage of the 1840 act establishing county and district constables, established civil service superannuation had become a compulsory contribution system, tightly controlled in terms of promised benefits and, where possible, administered at the local level (including the responsibility for any fund liability and its investment management) ( $3 \&$ 4. Vict. Ch. 88). Alternative funding sources were also sought such as, in the case of police superannuation schemes, the option for local Justices of the Peace to assign revenues from fines for drunken and disorderly conduct to local police superannuation funds (see $13 \& 14$. Vict. Ch. 87, 1850). 
Notwithstanding the 1834 act (4 \& 5 Will 4. Ch. 24) establishing a contribution-based system of superannuation schemes for the civil service, many public servants remained uncovered by pension schemes. In the case of teachers, successive governments encouraged teachers to contribute to friendly societies and generally rely upon the virtues of thrift and economy. Rhodes (1965) suggests that the case of teachers illustrates just how slow the transition was in society at large from patronagebased ex gratia pensions to general pension schemes. Governments were very reluctant to offer teachers the option to contribute to pension schemes believing, apparently, that such commitment would, in effect, commit government to the general provision of pensions. Nevertheless, the same administrative pressures that had prompted Parliament to streamline customs and excise pensions, slowly overcame government inertia. A series of reports and commissions of inquiry over the last half of the century concluded that the quality and efficiency of teaching would be greatly enhanced by the provision of superannuation schemes. Even so, it was only in 1898 that the act establishing "a universal, compulsory scheme for elementary school teachers" was passed; "other school teachers had to wait still longer" (Rhodes 1965, pp. 24-27).

While essential to the development of modern superannuation and pension fund management, government superannuation schemes did not cover all public servants. As well, Hannah (1986, p. 9) estimates that government employees were a very small proportion of the labour force (less than 3 percent in 1891). Over the last decades of the nineteenth century, public debate focused less on the nascent superannuation industry and more on old age poverty. Not only were the costs of the inherited system of poor relief increasingly onerous for government, the numbers of people living through to "advanced age" in penury was increasingly seen as an important moral and political issue. Commentaries at the time stressed over and over that many of the aged were destitute despite having planned for retirement. Distinctions were drawn between undeserving "tramps" and the deserving old aged poor who had been thrifty throughout their lives (see Alfred Marshall's evidence to the Royal Commission on the Aged Poor, 5 June 1893). By 1892, when the first act was passed providing meanstested age pensions for the destitute (55. Vict.), the political will had been mobilised to create a system of state-funded pensions. 
Notwithstanding the political movement towards universal, state-funded social security in Britain friendly societies, trades union and government superannuation schemes were to be remarkably important for the development of independent pension funds over the twentieth century. They provided legal and administrative templates for the design of private superannuation schemes. Dependence upon actuarial expertise inside and outside of government for assessing long term liabilities promoted the development of needed pension management expertise. Their reliance upon bond and equities markets for the investment of funds prompted the development of government and non-government institutions to regulate those markets. And their reliance upon trust law and the judicial process for regulation was widely copied throughout the Anglo-American world. Sass (1997) reports, for example, that in the US early twentieth century corporations and governments relied heavily upon English superannuation plans to design their own pension funds. And it is obvious that English trust law concepts have had a profound influence on Anglo-American conceptions of trustee responsibilities and autonomy (see Jobling 1994 for an exposition linking English, US and Australian experience). By contrast, even though Chancellor Bismarck led Europe with the introduction of state-guaranteed contribution-based old age pensions in 1889 (the law on invalidity and old age insurance), German and continental European occupational pension institutions were quite under-developed compared to England. They have remained so over the twentieth century (see Nottage and Rhodes 1986).

\section{Modern Industrial Society}

In evidence before the Royal Commission on the Aged Poor ( $5^{\text {th }}$ June 1893), Charles Booth noted that "modern times" had fractured the employment relation. By his account, rural-urban migration, the system of day-labour in London, and the residential separation of the employed from their employers had destroyed the traditional system of pension entitlements." It was almost impossible for a labourer to "get his old employer to take an interest in him as a human being" (p. 544). A "charitable middleman" was necessary to sustain the welfare of the old-aged. For Booth, the solution was to be found in state-funded retirement pensions and the passage of the 1908 Old Age Pensions Act 18 Edw. 7 Ch. 40). ${ }^{\text {vi }}$ For much of the twentieth century, the state has been seen as the most important institution guaranteeing old age well- 
being. At the same time, to understand to growth and development of employersponsored pensions and superannuation over the twentieth century also requires a better appreciation of the role of another, less charitable middleman. It was the growth of the modern corporation and the concomitant growth of the state as an employer over the first fifty years of the twentieth century that re-established the employment relation so necessary for the growth of non-state pensions.

The history of social security has been widely studied. It is hardly necessary to rehearse the arguments of so many other scholars. ${ }^{\text {vii }}$ Still a couple of points are worth making that are important in understanding the political forces behind the evolution of state-funded social security. At the time of the passage of the 1908 Pensions Act, the inherited nineteenth century system of voluntary contributions to sickness and deathbenefit schemes sponsored by friendly societies and trades unions was wholly inadequate with respect to the scope of old age penury. Notwithstanding liberal sentiment in favour of individual responsibility, and the attempts of governments to shore-up and expand the voluntary schemes, Booth and his urban middle class allies overwhelmed opposition inside and outside of Parliament to state-funded pensions, witness the critical response that greeted the Rothschild Report of 1898 which advocated no new pensions policies (see Sires 1954). In effect, nineteenth century liberalism was challenged by twentieth century social democracy before the great depression, the world wars and the cold war. In this context, the Beveridge Report of 1942 which set-out the logic for the UK welfare state could be seen as the culmination of a political movement forged together in the last years of the nineteenth century (compare with Abel-Smith 1994). ${ }^{\text {vii }}$

In between, the first world war and then the great depression both challenged the legitimacy of inherited institutions and profoundly under-cut the plausibility of nineteenth century liberalism. While no doubt contested and disputed, the great depression in particular re-defined the scope and responsibilities of the modern state (evident, of course, in the debate led by Keynes 1936 over government macroeconomic policy). In the United States, however, the great depression was to be the first opportunity to frame a national response to the problems of old-age social security. Previous attempts had foundered on a presumption in favour of states' welfare legislation. Nevertheless, poverty was widespread. And there were gross inequities between the states in the treatment of the old aged. The Social Security Act 
of 1935 was an attempt to stitch-together a national retirement policy based upon mandatory contributions. But it was compromised by funding problems, and little knowledge of the long run consequences of the system (compare assessment of the Institute of Economics in 1936 with Berkowitz 1991, 1997). It was only in 1950 that the US finally enacted a coherent public retirement system that surpassed the states' welfare systems.

As a consequence of the great depression, in both countries nineteenth century regulatory agencies were swept away and new institutions created relying upon centralised bureaucratic planning and control. These institutions were then added to and developed during the second world war as national economic planning and political integration became national priorities. Inevitably, the modern state's share of national income rapidly expanded matched by greatly increased numbers of civil service. If UK state sector employment was about 3 percent of the labour force in 1890, and if US government employment was about 2 percent of the labour force at the turn of the century, by 1950 public sector employment had grown to be more than 25 percent of the labour force in both countries employees (ignoring employees of the UK nationalised industries). Growth in public sector employment had two effects on pensions. The growth of employment combined with stability of job tenure greatly expanded the numbers of employees eligible for existing retirement benefits. At the same time, the nature and value of retirement benefits due government employees were liberalised including the additions of cost-of-living adjustments in both countries (and many other countries). As the demand for managerial labour increased, public sector pension benefits became essential reference points for the expanding number of private sector pension funds. ${ }^{\mathrm{ix}}$

Just as government had become a bureaucratic institution, so too had much of the private sector. Writing in the 1960s with respect to the US economy, Galbraith (1967, p. 74) noted "[n]othing so characterises the industrial system as the scale of the modern corporate enterprise." He cited data showing that corporations (not ownermanaged firms) dominated production and employment as well as the ownership and control of productive assets. For instance, in the 1972 revised edition Galbraith reported that in 1970 the 500 largest industrial corporations controlled 74 percent of "all assets used in manufacturing" and that "the 11 largest manufacturing, mining, retailing and wholesaling corporations employed 10 percent of the workers in these 
fields"(pp. 74-75). It is apparent that Galbraith's vision was true for many other western advanced economies and was to become the model of industrial growth for Japan and Korea; see Clark and Kim (1995). Essential to Galbraith's argument were two propositions: the modern corporation was more focused upon growth in the flow of revenue rather than short-term profits and; the management of the corporation was the product of the application of technology to planning and the routinisation of decision making in groups rather than individuals.

Galbraith wrote as if the modern corporation was an organic whole, conceived and developed as an economic institution in response to the inefficiency and instability of the market. Like Chandler (1977), he believed the modern corporation both required and created a new managerial class replacing the unquestioned authority of owner-managers with managers whose power was a product of their place in the functional hierarchy of a priori defined tasks and their need for co-operation from similarly placed managers in the organisation. Not surprisingly, the management of managers was itself routinised and their eligibility for pension benefits generalised rather than personalised. With the growth of corporations as the dominant form of industrial organisation came stability of employment, job tenure and the development of internal labour markets. In the twenty years after the end of the second world war, employer-sponsored pension plans proliferated and pension plan coverage of the private workforce greatly expanded. In the United States, coverage went from 22.5 percent in 1950 to 48 percent of the workforce around 1970. In Britain, coverage went from less than 15 percent just before the second world war to peak at about 50 percent in 1965. Of course, rates of coverage have been much higher in the public sectors of both countries compared to their private sectors.

In many corporations, managers were required to participate in the employersponsored pension plan. Benefits were, in effect, treated as deferred compensation and given preferential tax status. While Galbraith writes as if the imperatives of corporate management generalised and equalised the treatment of workers within and without the corporation, labour unions and governments on both sides of the Atlantic played important roles in broadening the participation of waged workers, women and minorities in employer-sponsored pension plans. Specifically, the 1949 decision of the US Supreme Court in Inland Steel which ruled that pension benefits were a form of wage compensation empowered US unions representing production workers to 
negotiate pension benefits with the major industrial corporations. ${ }^{\mathrm{x}}$ The United Steelworkers of America, the United Auto Workers, and many other leading (and competing) industrial unions began a long campaign to make pension benefits a customary part of any workers' compensation. This campaign, and other related campaigns in Britain, Australia and Canada, was only partially successful. Still, even now, patterns of pension coverage more often reflect the historical power of the industrial unions rather than cross-industry solidarity. For example, in Britain in 1991 coverage rates were highest in those sectors like coal mining (84 percent) and heavy manufacturing (67 percent) with a long history of union representation compared to sectors like retailing and services (34 percent) that have had weak union presence. ${ }^{\mathrm{x}}$

Furthermore, in the United States, the industrial unions played a major role in the passage of the first comprehensive federal legislation guaranteeing workers' pension rights and pension funding. The Employee Retirement Income Security Act of 1974 (ERISA) became the benchmark for many countries around the world seeking mechanisms to regulate and broaden the coverage of private pension schemes. ${ }^{\text {xii }}$ The political context of its passage are described in detail in Clark (1993) and Sass (1997). Two points should be kept in mind, however, about its underlying logic. At one level, it sought to establish in statute funding principles and standards so that workers' pensions would not be lost in the case of corporate bankruptcy or the like. It took the English common law heritage and built a regulatory framework around notions such as fiduciary duty relevant to the new industrial state. At another level, though, it imported notions such as "workers' rights" from civil rights legislation, the goal being to generalise pension entitlements in the workplace and protect those "rights" from arbitrary corporate decision making. Coincidentally, British also passed legislation dealing with discrimination in the provision of private pensions (the Social Security Pensions Act of 1975). However, it was to take another 15 years and the intervention of the European Court of Justice before UK legislation had the same force on this issue as the US legislation. xiii $^{\text {. }}$

Arguably, Galbraith caught the new industrial state at its zenith. Since the mid 1970s, corporate restructuring has been the operative strategy in much of the AngloAmerican world. In its initial stages, corporate restructuring sought to escape the boundaries imposed by the inherited configuration of production. Growth in the flow of revenue was to be achieved by diversification and conglomeration. Corporations 
were to become diverse portfolios of income, ideally structured so as to balance risks against one-another in the interests of sustaining the stability of corporate growth. These plans were never realised. As Hamel and Prahalad (1994, p. 5) have noted, Galbraith's pantheon of the leading industrial corporations have been attacked in their core markets. They have failed to "keep up with the accelerating pace of industry change." The form, functions and ownership of the modern corporation have become essential variables in the search for competitive advantage. And for many managers, cost efficiency has been an important driving force behind corporate restructuring. Not only have many hundreds of thousands of workers lost their jobs as corporations have sought to simultaneously downsize and increase labour productivity, recurrent waves of mergers and acquisitions have drastically affected job tenure through to the highest levels of corporate life (Harrison 1994).

In this context, the employment relation and pension benefits have taken the brunt of corporate re-engineering. Indeed there are many instances where corporations have sought legal and not so legal ways of discounting their pension liability or creaming-off so-called "excess" reserves (Clark 1993). Rates of private employer-sponsored pension plan coverage plateaued in many countries more than a decade ago. Now there is evidence that rates of coverage in the Anglo-American world are beginning to decline as the nature of work itself begins to change and contingent contracts become more common for the average male unionised employee. Furthermore, the nature and design of employer-sponsored pension plans are also significantly changing. Whereas defined benefit plans were once the standard model, new models of pension plan management like defined contribution plans have become very important, just as (in the US) 401(k) plans have been introduced to shift the apparent financial risks and administrative burdens of defined benefit and defined contribution plans to beneficiaries. ${ }^{\text {xiv }}$

\section{Causes of Pension Fund Capitalism}

I have argued that the recent growth of pension fund assets in the Anglo-American economies can be traced, in part, back to: (S1) the development of English pensionrelated institutions during the nineteenth century; (S2) the re-establishment of longterm employment contracts in the first half of the twentieth century and their expansion immediately after the second world war; and (S3) the latent political significance 
attached to private, market-based solutions for retirement planning. In making these claims, I suggested that English pensions institutions were profoundly important in shaping and affecting subsequent developments in pension provision in the rest of the Anglo-American world. It is also apparent, however, that the diffusion of pensionrelated innovations has not been unidirectional. In particular, US pension legislation has been an important reference point shaping other countries' anti-discrimination policies, and was very important in re-shaping UK regulations in the wake of the Maxwell scandal (Goode 1994a, 1994b). Likewise, the new Australian system of mandatory pension contributions may have long-term consequences for retirement funding policy in the UK and elsewhere.

Here I will refer to the historical roots of the current Anglo-American pension system as structural determinants (S). In my judgement, however, they are not equally important. Their identification (S1) through to (S3) reflects a deliberate order of importance beginning with the design and regulation of private pensions in the nineteenth century. Having established a pension system which could be relied upon, the continuity of employment was an essential requirement for the long term accumulation of pension contributions. While I have emphasised the employment relation between employers and employees, it is apparent that other models can deliver the kind of continuity necessary to sustain asset accumulations. For instance, the multi-employer, jointly trusteed pension funds established by unions and employers in US craft industries in the early years of the twentieth century achieved a kind of continuity that survives to this day. Furthermore, it seems that the slow adoption of state-funded social security systems in much of the Anglo-American world sustained, perhaps by default, the private pension institution. Even in the UK and Australia, which both embraced the principles of the Beveridge Report (1942), governments of the day failed to deal adequately with the overlap and inter-relationships between social security and private pension provision.

The pension institution, the employment relation, and the latent preference for market solutions are structural determinants of Anglo-American pension fund capitalism. The notion of causality implied by this argument is quite particular and, perhaps, unusual with respect to the social sciences. Causality is often-times equated with generality and laws of nature (systems or regimes of institutions). Humean causality first establishes general propositions and then uses specific instances to either 
illustrate or test those general propositions (Ehring 1997). For example, it might be supposed that there is a (general) necessary relationship between pension fund accumulation and the employment relation, and that what I have suggested by way of historical examples are evidence in support of that proposition. By this logic, causality is an abstract property of whole systems (like capitalism). This is not really my argument, as I have tried to suggest by a brief reference to US craft union pension plans. Ehring (1997, p. 15) captures the spirit of my analysis in the following manner: "[c]ausal inquiry is a matter of providing first a breakdown or analysis of the constituents of the relevant trope [or determinant] at a time $t$, then a history that indicates how these components came to be realised in their incarnation at $t$ through property persistence, fission, and fusion." This is the basis of Figure 1.

These structural determinants of pension fund capitalism have persisted over many years, even if their influence has varied over time (events) and space (nations). The structural determinants have set the broad parameters of pension fund capitalism, distinguishing in the aggregate the Anglo-American financial system from the German and continental European financial systems. But also embedded in the previous historical analysis are a set of what might be termed second-order (SO) determinants or causes of pension fund capitalism. These determinants have amplified and extended the boundaries of the inherited pension system in the following ways: (SO1) postwar economic and demographic growth greatly increased the numbers of workers eligible for private pension coverage; (SO2) just as the rapid growth of government employment automatically extended the volume and rate of coverage of all workers; while (SO3) government anti-discrimination legislation mandated eligibility for private pensions of groups of workers previously arbitrarily excluded by corporate fiat. In essence, postwar growth, the state sector, and government policy together profoundly affected the numbers and rate of actual and potential pension coverage. The structural determinants provided a framework for the second-order determinants to promote growth in coverage, rates and numbers.

In this respect, it is difficult to rank in importance the second-order causes of the growth of coverage. There was clearly considerable interaction between the first and second determinants. Competition for labour between the industrial and state sectors in an environment of economic growth both promoted coverage and extended the scope of benefits and the costs of private pension coverage to employers. In those 
industrial sectors with strong union representation, the value of pension benefits continued to increase well after the economic vitality of those sectors had been eclipsed by new competitors (domestic and international), and long-term shifts in the global and local market configuration of demand. Indeed, it could be argued that government policy mandating equality of eligibility and benefits came after the peak in employment in the industrial and state sectors that had led postwar economic growth. In the US context, anti-discrimination legislation has significantly affected the pension coverage rte of full-time women employees, increasing from 38 percent in 1972 to 48 percent in 1993. Even though the numbers and relative significance of unionised male employees are declining, the extension of pensions benefits to women has tended to stabilise (even slightly increase) the overall coverage rate.

Whereas La Porta et al. (1996, 1997) distinguished between the AngloAmerican and continental European financial systems by reference to the English common law tradition, I have argued that the structural determinants of pension fund capitalism can be found in English and American financial institutions and their regulation. For La Porta et al. these kinds of structural determinants drive contemporary differences in financial markets' forms and functions. Here, however, I have also argued that the second-order determinants of pension fund capitalism have amplified and extended the boundaries of the inherited system of pension fund capitalism. In this respect, I would argue that invoking inherited structural determinants as the causes of systems' differences is an inadequate explanatory strategy given the extent to which the identified second-order determinants have played a major role in promoting the growth of pension fund capitalism. Clearly, workers' entitlements to pensions remain quite vulnerable to changes in the underlying employment relation. But growth in the system itself has gone beyond the logic of implied by the employment relation.

Identification of the structural determinants and second order causes of pension fund capitalism has allowed us to better appreciate the connection between the inherited institutional framework and then growth in pension coverage after the second world war. But this connection remains silent on a crucial issue: the enormous growth of pension assets in the Anglo-American economies since the late 1960s. The combination of structural determinants and second order conditions is insufficient as a complete explanation of the differences between the Anglo-American economies and 
the German and continental European economies. Why? German and many continental economies have shared most of the previously identified causes of pension fund capitalism. Even if they did not begin the twentieth century with the same pension-oriented institutional and regulatory structures, German corporations have provided pension plan options for their employees. Even if state-funded social security has dominated retirement planning in Germany, economic and demographic growth, state sector employment growth, and anti-discrimination legislation could be argued to have had similar effects or the potential to expand pension coverage rates.

And yet, notwithstanding similar pension coverage rates, the growth in pension assets has been astonishingly different. The final step, then, is to introduce a set of third-order causes of pension fund capitalism that can account for this most important aspect of the Anglo-American system. Three separate but mutually reinforcing elements of the Anglo-American system have converted stable or even declining coverage rates into a profoundly different financial system: (TO1) the incremental collection and accounting of individuals' pension contributions; (TO2) customary and then legally-enforced requirements to fund private, employer-sponsored pension liabilities; and (TO3) the decision of many larger plan sponsors to centralise collected pension contributions in pension funds as opposed to out-sourcing individual's pension dues and entitlements to the insurance sector. In combination, TO1 to TO3 have promoted the formation and maintenance of pension funds, distinct from and in competition with the insurance systems of the Anglo-American economies.

By custom and convention, and later by virtue of judicial rulings to the effect that pension benefits are a form of remuneration, pension plan sponsors in the AngloAmerican economies have organised the collection of pension contributions as part of their normal wage and salary payment systems. So, for example, corporate pension plans that were either based upon employer contributions or a combination of employer and employee contributions collect those contributions as workers are paid (hourly, daily, weekly, and monthly). Indeed, many of the major industrial union contracts for "blue-collar" workers in the US and Canada, the UK and Australia have specified in great detail the hourly contribution rate by class and status of worker. Since many employers provided defined benefit (final salary) plans, it was possible for plan sponsors to forecast their long term liability and adjust (with the agreement of their unions) incrementally the wage and salary based contribution rate. This does not 
mean that pension plans were necessarily fully funded. For many years, plan beneficiaries relied upon the inherited common law tradition of trustee fiduciary duty to ensure that sponsors lived-up to their obligations. However, celebrated instances of corporate bankruptcy and malfeasance prompted the passage of legislation like ERISA setting standards for the funding of private pension plans and, in most Anglo-American countries, establishing regulatory bodies to monitor funding arrangements.

Many pension plans are still relatively immature, the product of postwar economic and demographic growth. Thus incremental collection combined with the on-going funding of expected liabilities has sustained a massive long-term inflow of assets to invest. More often than not, the larger plan sponsors have centralised the flow of assets and liabilities into sponsored pension funds and have relied upon the burgeoning investment management industry to manage the investment process (see Clark $1998 \mathrm{~b}$ on the functional and spatial structure of the industry). Whereas the insurance sector has played a significant role in the past in managing firms' pension obligations, since the second world war the sector has seen its share of assets systematically decline and become increasingly reliant upon small firms and plan sponsors for their business. The concentration of larger pension plan sponsors' assets into separate pension funds is a distinctive and profoundly important aspect of the Anglo-American world. There are hundreds of thousands (even millions) of pension plans in the Anglo-American world. Only a small fraction have more than 50 participants. Only an even smaller fraction have more than $£ 10$ million in assets. But those that do exert enormous influence on the structure of Anglo-American capitalism.

The contrast with the German pension and financial system is stark. At a time when Anglo-American corporate and government pension funds where rapidly expanding their coverage (numbers and rates of employees), in the late 1950s West Germany (as it was) completed the social security system begun by Bismarck in the late nineteenth century. Participation was made mandatory for all private, nonprofessional employees, with close links established between the rate of contributions and the level of promised benefits. It was deliberately designed to be a PAYG system. As Queisser (1996, p. 5) notes, with respect to the current system, it "has practically no funding, apart from a liquidity reserve amounting to one month's expenditure." At present, the more than 2.5 million state sector employees do not participate in this system; their retirement systems are based upon employer contributions also funded on 
a PAYG basis (by local, state, and federal governments). There are, as well, a large number of retirement schemes for a small number (relatively speaking) of professionals separate from the social security system. Only twenty percent of these schemes are fully funded. Very simply, the potentially important post-war effects of economic and demographic growth and state sector employment growth have been muted in Germany by the promotion of PAYG public-sponsored social security systems.

Of course, the rate of employer-sponsored pension coverage is significant compared to the Anglo-American world. As noted above, the 1990 German occupational pension coverage rate was about 46 percent of all employment with about 33 percent of covered employees in company sponsored schemes. However, the growth of pension assets in those pension plans has been very low compared to the Anglo-American world. Why? Principally because more than half of the covered employees participate in plans that use the book reserve method of accounting for pension liability. Much has been written of this system of corporate accounting. According to Edwards and Fischer (1996, p. 55) this means that the "enterprise makes pension provision for its employees by investing its contributions to employee pensions within the enterprise itself." There are complicated accounting standards and requirements regulated by the government. And there has been considerable debate about the consequences of this arrangement for corporate-banking relationships, and the long-term development of German industry (see Roe 1994). By contrast, the right to self-invest is closely regulated in the Anglo-American world and, in any event, even when firms do self-invest a small portion of its contributions, these funds must be first taken out of the corporate accounting system as a deduction and full account taken of the implied long-term liability.

The book reserve system basically internalises pension assets. While it accounts for the majority of pension "assets" in Germany, it is not a particularly popular mode of pension provision for the average German firm. Queisser believes that less than 14 percent of firms manage their plans in this manner and those that do are large firms not small firms. The vast majority of firms (nearly 70 percent) still prefer to arrange direct insurance for their employees outside of the firm. As Edwards and Fischer note, the insurance companies that offer such services more often than not invest pension contributions in long-term corporate and government bonds. The obvious alternative model and second in significance to the book reserve system in 
terms of covered employees, is a separate employer-sponsored pension fund (the Anglo-American model). But this is also relatively unimportant. Queisser reports that about 28 percent of firms have sponsored pension plans involving about 20 percent of covered employees. The majority of these plans are offered by larger firms and are typically under-funded (comparing assets against expected liabilities). In fact, as the industry newspaper Pensions and Investments (September 15, 1997; Vol 25, \#19) has noted, of the world's 300 largest pension funds only 7 German funds qualify for inclusion and four of the seven have less than \$US6 billion in assets even though most are major, global corporations. ${ }^{\mathrm{xv}}$

By this account, the German and continental European financial systems are different because they share neither the structural determinants nor the third-order determinants of Anglo-American pension fund capitalism. There are reasons to suppose that the gap between these systems is not so significant with respect to the second-order determinants. It could be argued, for instance, that postwar economic and demographic growth, state sector growth and European initiatives to equalise the treatment of men and women with respect to pension entitlement have tended to increase the numbers and rates of pension coverage in Europe and the Anglo-American world. But just as significantly, the processes whereby pension contributions are collected (or not collected), are accounted for within firms, and held against the net worth of firms in the market have conspired to drastically curtail the rate of growth of pension assets. In this respect, it might also be argued that these financial practices are, themselves, directly attributable to basic, structural differences between these economic systems. In a sense, these financial practices derive from very different financial and institutional traditions already apparent in the last years of the nineteenth century and persisting through much of the twentieth century and beyond.

\section{Pension Funds and Global Capitalism}

So far we have dealt with the structural and contingent causes of the growth of pension assets in the Anglo-American world, remaining largely silent about the status of pension funds as institutions. Here I reintroduce the funds into the narrative indicating how and why they are so important in the world of finance. In doing so, we begin with a set of observations about the nature and scope of pension coverage noted previously but hitherto not brought to the center of discussion. While many workers 
belong to very small plans (sponsored by firms with 10 or less employees), the larger the sponsor the bigger the coverage rate. The US Department of Labor (1994) reported very low coverage rates for the smallest firms (13 percent) but also showed that coverage rates rise in proportion with firm size (53 percent for firms with 100-299 employees and 73 percent for firms with more than 1000 employees). Historically, it is apparent that larger firms have tended to offer defined benefit plans. This is changing, of course, as medium to large firms increasing come from industries that have not experienced significant levels of unionisation. Even so, these firms dominate the coverage of workers and have accumulated large reserves of pension assets to pay for promised benefits.

With the introduction of compulsory contributions, the pattern of coverage by firm size in Australia is more complicated. Many numbers of new plans have been created over the past few years, predominately by small firms having to comply with federal regulations. In many cases, small firms have joined large industry-sponsored pension plans while others have sought the assistance of insurance industry-sponsored master trusts and the like. ${ }^{\mathrm{xi}}$ Throughout the Anglo-American world, the increasing volume and complexity of government-mandated reporting requirements and closer scrutiny of plan sponsors and trustees with respect to the interests of plan beneficiaries have all added significantly to the costs of operating pension plans. Small and medium sized enterprises have found such regulations and reporting requirements a costly burden on owner/managers. There are significant economies of scale in the management of pension funds, especially in processing and accounting for the flow of contributions and benefits in and out of the fund. Data on plan economies of scale are, however, notoriously difficult to obtain. Nevertheless, industry commentators believe administrative costs are better managed if there are at least 1000 plan participants (about \$US100 million in assets) and there are considerable economies of scale with larger numbers of plan participants (more than 10,000 participants, about \$US1 billion in assets). ${ }^{\mathrm{xvii}}$

Given the limitations of data, it is difficult to take this point much further. In any event, the economic structure of the pension fund investment industry is dealt in more detail in Clark (1998b). However, it is important to acknowledge that industry research suggests there is a close correlation between the size of a fund and the demand for sophisticated financial products. Greenwich Associates (1996) have 
conducted wide-ranging questionnaire surveys and interviews of a stratified sample of large and small, public and private US pension funds. They show that the larger private funds use financial futures, stock index futures, hedge funds and derivatives. This is especially the case for funds with more than \$US1 billion in assets although they also show that a significant but smaller proportion of private funds (\$US250 million in assets or more) also use these products. Their data also suggest, however, that only the largest public funds use these products despite the general interest of all public funds in venture capital investments. On the question of corporate governance, one of the most contentious issues in the Anglo-American financial world (and one which threatens continental European practices), the Greenwich data reinforces the point: the largest public and private funds take the most interest in corporate governance. Smaller funds leave the issue to their investment managers.

There can be little doubt that the larger funds have played important roles in Anglo-American financial markets. They have been consumers of financial services, promoting the development of global financial flows management and accounting. They have also been the consumers of sophisticated financial products, thereby promoting the process of product innovation. They have been the consumers of trading systems, playing significant roles in promoting the efficiency and reliability of third-party markets and trading institutions. Furthermore, they have been an essential component in the massive increase of traded capital in Anglo-American capital markets over the last couple of decades. In the US, households have become less and less important as the owners of equities while institutional investors have become much more important. In 1950, households owed 91 percent of all equities whereas in 1994 they owned 48 percent of all equities. Public and private pension funds owned less than 1 percent of all equities in 1950 whereas they owned more than 25 percent of all equities in 1994. Combining pension funds with other institutional investors (mutual funds), these institutions now control more than 45 percent of all equities. Furthermore, pension funds and institutional investors more generally defined control the majority of stock of the largest 1000 US corporations. Similar patterns have been observed for the UK, Canada and Australia.

In these ways, the connection between finance and economic growth in the Anglo-American economies has been realigned around new institutions and modes of financial intermediation (compare with King and Levine 1993). In this context, La 
Porta et al. (1997, p. 1131) ask a simple question: "[w]hy do some countries have so much bigger capital markets than others?" Their answer has a simple, unidirectional causal logic. They begin as I have done in Figure 1 with the legal-cum-institutional framework of financial markets distinguishing between various traditions including English common law and continental European models. Their next step in the causal chain is to argue that as a result of those inherited frameworks, identified groups of countries have very different rules and enforcement procedures regarding the protection of investors' equity. The last step in their analysis is to suggest that because of these differences countries' markets vary in terms of their size (the number and diversity of stocks offered for sale) and volume (the trading of companies' stocks). Comparing various European traditions, they conclude that apparent differences in countries' size and significance of equity markets can be explained by the underlying legal framework. Clearly, their argument is related to my own concerning the causes of growth in Anglo-American pension assets. But it is also possible that the size and significance of capital markets can be explained by the demand for equities- the product of the structural and contingent causes of pension fund capitalism.

Anglo-American pension funds are also active participants in global securities' markets. On average, UK pension funds allocate 80 percent of their assets to equities, including 20 percent allocated to international equities. This will change as the recent pension funding regulatory reforms force funds to shift towards a more balanced asset allocation formula. Nevertheless, emerging markets and other significant international markets will remain an important part of UK pension portfolios. In the US, most funds have had quite limited allocations to international equities (often less than 5 percent). This depends, somewhat, on the nature of pension plan benefits. Defined contribution plans tend to allocate a larger portion of assets to higher risk, short term investments. Defined benefit plans on the other hand tend, inevitably, to balance short term equities against long term bonds given their expected long term liability. ${ }^{\text {xiii }}$ Notwithstanding these different patterns of investment Anglo-American pension plans are, inevitably, participants in the global economy. The integration of the principal securities markets over the past twenty five years via advanced telecommunications has enabled small markets like Hong Kong to have significant short term effects on the performance of the largest markets in London, New York and Tokyo. Even the most parochial US public pension fund has a stake in the performance of global and national markets. 
Recurrent but unpredicted market crises have affected pension funds' capital accumulations. The most recent example is, of course, the global crisis initiated by the Hong Kong market. It is also apparent that such events are often short-lived obscuring considerable year to year fluctuations and long term market discounting. ${ }^{\mathrm{x} x}$ For example, for the period ending September 30, 1997 the Salomon Brothers EMI World Index (excluding the US) of international equities recorded a third quarter decline of 4.04, a year to date gain of just 0.97 translated as an annualised gain of 0.35 and a three year annualised gain of 3.31. Japan and the emerging markets have contributed significantly to the poor performance of global market indexes. The Russell index for Japan recorded a third quarter decline of -15.21 , a year to date decline of -8.33 annualised as -19.57 and a three year annualised decline of -9.28. The J P Morgan fixed income emerging markets index recorded a third quarter decline of -9.17 and a year to date decline of -4.60 (against a three year annualised increase of 4.15). AngloAmerican pension funds have responded to apparent market weaknesses and have exacerbated these patterns as they have shifted assets towards the core markets in the hope of reaping the rewards of the last phases of the bull market.

We should be careful not to over-estimate the significance of non-AngloAmerican securities' markets. While the Japanese market is important in terms of its share of global traded volume, the US and UK markets far out-weigh its volume and have enormous significance for the performance of related markets in Canada and Australia, as well as Europe. In fact, while the Japanese market recorded a three year annualised decline of -9.28 over the same period the Salomon Brothers US Treasury Bill (3 month) index recorded a three year annualised gain of 5.41. In other words, simply holding assets as convertible cash has been a far superior investment strategy to investment in Japanese and emerging market equities. At the same time, AngloAmerican equity markets have recorded extraordinary three year gains: 14.77 for Australia, 18.66 for Canada, 22.48 for the UK and 28.75 for the US. Few would contend that this extraordinary performance is normal when compared over the entire postwar second world war period, and few would suggest that it is sustainable over the long term. Many commentators have recalled the circumstances of the $1987 \mathrm{crash}$, arguing that herd behaviour in the market can easily switch from reinforcing the bull market to precipitating a bear market. 
Whatever the doubts regarding the current bull markets' sustainability, and notwithstanding doubts about the desirability of "playing roulette" with the real economy (see Kuttner 1997, p. 160), the recent performance of Anglo-American financial markets is part and parcel of a long term structural transformation in the financial sectors of many Anglo-American economies. Through to the early 1970s, many pension funds' assets were relatively small compared to banks and other related financial institutions. The postwar expansion in plan participation had not, at that time at least, translated into huge holdings of assets. Moreover, many US funds had conservative investment policies often preferring to hold government bonds rather than equities while typically holding rather than trading its equity portfolio. ${ }^{\mathrm{xx}}$ As time has elapsed, however, the gap between the returns of market equities and government bonds has widened just as the gap between active trading as opposed to passive holdings has also widened. Equities have out-performed bonds over the past twenty five years even though short periods of high inflation in the major economies have episodically advantaged bonds over equities. As this pattern emerged in the 1980s, Anglo-American pension funds began to slowly switch more assets towards equities, and in periods of market run-ups the switching process has dramatically accelerated.

As a consequence of the rapid growth in assets and the apparent value of more active investment strategies, pension funds have had to develop their own internal expertise or purchase related services from the market. In recent years, the burgeoning volume of many larger funds' assets coupled with the need to provide more complex services to fund participants including, in the US, 401(k) options, has overtaken many pension funds' internal accounting and flow-of-funds management practices. At the same time, the growth of financial service companies specialising in these functions and the development of sophisticated real-time accounting software amongst some of the leading mutual fund companies together have promoted the development of an external market for plan management. Reinforcing these trends has been the need of pension funds for expert advice on investment strategy and specialised investment management services. This has been especially important for smaller funds, unable or unwilling to invest given the costs of hiring and maintaining staff and the opportunity costs of poor market information (compared to specialised managers). Even larger funds now outsource many investment and flow-of-funds functions. In combination, over the last twenty five years a global investment management industry has been formed around 
the needs of the Anglo-American pension funds-an industry that now challenges the banking institutions of continental Europe in their own markets.

\section{Conclusions}

In this paper, I sketched a causal framework which accounts for the growth of pension assets in the Anglo-American world and distinguishes that experience from the German and continental systems excluding the Netherlands and Switzerland. The causal framework is both hierarchical in order and additive in effect: structural determinants inherited from English initiatives during the nineteenth century set the basic parameters of the Anglo-American pension system during the twentieth century; second-order determinants particularly significant after the second world war have amplified and extended pension coverage rates in the private sector; and third-order determinants relating to the funding of pension liability have, in combination with the other two sets of determinants, generated an enormous flow of assets into pension funds. While the German and continental European systems share in some of these determinants (like economic and demographic growth after 1950) and appear to share similar levels of pension coverage rates, in the end the systems are remarkably different. Pension fund capitalism will remain an Anglo-American phenomenon over much of the coming century.

In part, difference will persist because, as Hollingsworth and Boyer (1997, p. 3) put it, "[m]arrest and other mechanisms for co-ordinating relationships among economic actors place constraints on the means and ends of economic activity to be achieved in any society." The particular mix of markets, social institutions and state regulations that are the basis of the Anglo-American pension system are different from the German system. To suppose that there are simple solutions for funding German retirement liability in the near future by replicating aspects of the Anglo-American pension system surely ignores the inherited ensemble of causal determinants that create the whole. This does not mean that change is impossible, or that economic systems are impervious to the adoption of external initiatives. Such propositions are manifestly implausible. Nevertheless the framework sketched above which combines structure and contingency suggests that simple, partial solutions are bound to be problematic to implement and inevitably limited in effect. 
On the other hand, to imagine the Anglo-American system is far superior or necessarily more efficient would be to ignore the fragility of some of the major elements that make up the whole system. In particular, stable or declining coverage rates, and changes in the nature and scope of promised pension benefits illustrate just how vulnerable the Anglo-American system is to the employment relation, and to the economic and institutional environment in which it is negotiated. So much has changed over the past thirty years directly threatening private-sponsored arrangements for retirement saving. Whereas Galbraith (1970) could write with assurance about the rise of the "new industrial state" and the array of large corporate and state institutions that underpinned the associated employment relations, the new world of the twentyfirst century is one of increased insecurity of employment tenure, increased mobility (voluntary and involuntary) over a life-time of work, and heightened competition between firms caught-up in the increasingly global market for corporate control. We have not returned to the dark world of Victorian London; history does not simply repeat itself as if bound by a never-ending cycle of given causes and events (Carr 1961). But it is clear that the whole Anglo-American institution of pension fund capitalism is very vulnerable to the stability of second-order causal determinants.

There is, however, another important point to be made about the persistence of systems and their differences. If the Anglo-American system is vulnerable to disruptions in second-order determinants, it may also be thought vulnerable to itself. Even though coverage rates are stable or slightly declining, the net inflow of pension assets continues unabated. Over the past few years, the run-up in Anglo-American security markets has been nothing short of phenomenal; notwithstanding significant differences between markets' performances, institutional investors have fuelled an extraordinary increase in stock prices reinforcing pension funds' reliance upon these markets as their primary focus of investment. The run-up in stock prices has had many effects. One important effect has been to lower the effective cost of mergers and acquisitions. Another related effect has been to increase the relative value of private placements (investments in leverage positions). In combination, a new round of corporate restructuring is underway. This time, the market for corporate control is reaching into the heart of Europe. In effect, the speculative forces unleashed by the massive net inflow of pension assets in the Anglo-American economies can be 
increasingly seen as separate from, even antagonistic to, the corporations that sponsor pension plans.

By this logic, the rise of global finance as a system of institutions and economic agents rivalling the better understood institutions and agents of production is closely related to pension fund capitalism. Even so, some recent writers appear to imagine that global finance is a rootless creature, somehow spatially and functionally disembodied from the world that has given it life. For example, Hirst and Thompson (1997) identify a set of causes of increased international capital flows emphasising "features" such as floating exchange rates, OPEC funds, third world debt, and currency and trading liberalisation. They suggest that while these features of the international capital system have overtaken systems of real production, these features are ephemeral rather than structural and therefore reversible rather than endemic. Now it may be the case, as they suggest, that the re-regulation of currency speculation and the management of trading blocks in relation to exchange rate fluctuations may dampen global financial volatility. But Hirst and Thompson have only identified the immediate objects of institutional investors and their client funds. Hirst and Thompson fail to recognise the origin and growth of financial flows in the Anglo-American economies and the extent to which the related institutions have (or do not have) an interest in spatially bounded as opposed to spatially unbounded investment strategies.

Historically, it would seem that pension funds and the related investment institutions have been quite myopic (geographically speaking). Until very recently, and in contrast with the Australian and UK experience, few US pension funds have had a significant international equity portfolio. Of course, it is arguable that by simply investing in US blue-chip securities, pension funds have achieved international exposure given the reliance of large US companies upon their international markets. And it is also the case that many public sector pension funds have been limited in their ability to invest in traded securities, let alone international securities. Likewise, many European governments have closely regulated their pension funds' international investments claiming a national interest in the geographical destination of assets as well as an interest in the nationality of the firms managing the investment process. And yet, even with these restrictions, the volume of internationally mobile Anglo-American pension assets is increasingly affecting whole nations' economies and the international system of debt management. As is the case domestically, the separate interests of plan 
sponsors and those who control and manage pension assets conspire in the international context to put in play the interests of the Anglo-American economies in relation to other global economic interests and opportunities.

Notes

References

Abel-Smith, B. 1994. The Beveridge Report: its origins and outcomes. In Beveridge and Social Security: An International Retrospective edited by J. Hills, J. Ditch and H. Glennerster. Oxford: Clarendon Press, pp. 10-22

Berkowitz, E.D. 1991. America's Welfare State: From Roosevelt to Reagan. Baltimore: Johns Hopkins University Press

Berkowitz, E.D. 1997. The historical development of social security in the United States. In Social Security in the $21^{\text {st }}$ Century edited by E.R. Kingston and J.H. Shulz. Oxford: Oxford University Press, pp. 22-38

Blake, D. 1995. Pension Schemes and Pension Funds in the United Kingdom. Oxford: Clarendon Press

Carr, E. H. 1961. What is History? London: Macmillan

Chandler, A. 1977. The Visible Hand: The Managerial Revolution in American Business. Cambridge MA: Harvard University Press

Clark, G.L. 1993. Pensions and Corporate Restructuring in American Industry: A Crisis of Regulation. Baltimore: Johns Hopkins University Press

Clark, G. L. 1998a. The retreat of the state. Working Paper 98-1. Oxford: School of Geography, University of Oxford

Clark, G. L. 1998b. The functional and spatial structure of the investment management industry. Geoforum (forthcoming) 
Clark, G. L. 1998c. Why convention dominates pension fund trustee investment decision making. Environment and Planning A (forthcoming)

Clark, G. L., Burkitt, J., Caldow, W. and Jobling, M. 1996. The superannuation industry in Australia. Working Paper 7. Melbourne: Australian Housing and Urban Research Institute

Clark, G. L. and Kim, W.B. (eds.) 1995. The Asian NIEs in the Global Economy. Baltimore: Johns Hopkins University Press

Clark, R. C. 1981. The four stages of capitalism: reflections on management treatises. Harvard Law Review 94, 561-82

Craig, P. and de Burca. G. 1995. E.C. Law: Text, Cases and Materials. Oxford: Oxford University Press

Davis, E. P. 1995. Pension Funds: Retirement Income Security and Capital Markets. An International Perspective. Oxford: Clarendon Press

De Ryck, K. 1996. European Pension Funds: Their Impact on European Capital Markets and Competitiveness. London: European Federation for Retirement Provision

Edwards, J. and Fischer, K. 1994. Banks, Finance and Investment in Germany. Cambridge: Cambridge University Press

Ehring, D. 1997. Causation and Persistence: A Theory of Causation. Oxford: Oxford University Press

Esping-Anderson, G. 1990 The Three Worlds of Welfare Capitalism. Oxford: Polity Press

Fogelson, R. 1984. Pensions: The Hidden Costs of Public Safety. New York: Columbia University Press

Galbraith, J.K. 1967. The New Industrial State. London: Andre Deutsch 
Goode, R. 1993. Pension law Reform: The Report of the Pension Law Review Committee. London: HMSO

Goode, R. 1994a. Occupational pensions: securing the pension promise. The Denning Law Journal 15-25

Goode, R. 1994b. Defining and protecting the pension promise. Journal of the Institute of Actuaries 121, 161-77

Grant, W. 1997. Perspectives on globalisation and economic coordination. In Contemporary Capitalism: The Embeddedness of Institutions edited by J. R. Hollingsworth and R. Boyer. Cambridge: Cambridge University Press, pp. 319-36

Grundger, F. 1994. Beveridge meets Bismarck: echo, effects, and evaluation of the Beveridge Report in Germany. In Beveridge and Social Security: An International Retrospective edited by J. Hills, J. Ditch and H. Glennerster. Oxford: Clarendon Press, pp. 134-53

Hamel, G. and Prahalad, C.K. 1994. Competing for the Future. Boston: Harvard Business School Press

Hannah, L. 1986. Inventing Retirement: The Development of Occupational Pensions in Britain. Cambridge: Cambridge University Press

Harrison, B. 1994. Lean and Mean. New York: Basic Books

Harrison, D. 1995. Pension Fund Investment in Europe. London: Financial Times Publishing

Hawley, J.P. and Williams, A.T. 1996. Corporate governance in the US: the rise of fiduciary capitalism. Working Paper. Moraga CA: St. Mary's College of California

Hills, J., Ditch, J. and H. Glennerster, H. (eds.) 1994. Beveridge and Social Security: An International Retrospective. Oxford: Clarendon Press 
Hirst, P. and Thompson, G. 1997. Globalisation in question: international economic relations and forms of public governance. In Contemporary Capitalism: The Embeddedness of Institutions edited by J. R. Hollingsworth and R. Boyer. Cambridge: Cambridge University Press, pp. 337-60

Hirst, P. and Zeitlin, J. 1997. Flexible specialisation: theory and evidence in the analysis of industrial change. In Contemporary Capitalism: The Embeddedness of Institutions edited by J. R. Hollingsworth and R. Boyer. Cambridge: Cambridge University Press, pp. 220-39

Hollingsworth, J. R. and Boyer, R. 1997. Coordination of economic actors and social systems of production. In Contemporary Capitalism: The Embeddedness of Institutions edited by J. R. Hollingsworth and R. Boyer. Cambridge: Cambridge University Press, pp. 1-48

Institute of Economics 1936. The Recovery Problem in the United States. Washington DC: Brookings Institution

Jobling, M. 1994. A legal perspective on targeted superannuation fund investment: Working Paper 1. Melbourne: Australian Housing and Urban Research Institute

Jones, G. Stedman. 1971. Outcast London: A Study in the Relationship Between the Classes in Victorian Society. Oxford: Clarendon Press

Keynes, J.M. 1936. The General Theory of Money, Interest and Employment. London: Macmillan

King, R. and Levine, R. 1993. Finance and growth: Schumpeter might be right. Quarterly Journal of Economics 108, 717-38

Kuttner, R. 1997. Everything for Sale: The Virtues and Limits of Markets. New York: Knopf 
La Porta, R., Lopez-de-Silanes, F., Shleifer, A. and Vishny, R. 1996. Law and finance. Working Paper 5661. Cambridge MA: National Bureau of Economic Research

La Porta, R., Lopez-de-Silanes, F., Shleifer, A. and Vishny, R. 1997. Legal determinants of external finance. Journal of Finance 52, 1131-50

Marden, P. and Clark, G. L. 1994. The Regulation of Private Pensions (Superannuation) and Strategic Unionism in Australia: Learning from the United States. Monash Publications in Geography, Number 44. Clayton VIC: Department of Geography and Environmental Science, and National Key Centre in Industrial Relations, Monash University

Martin, R. L. and Minns, R. 1995. Undermining the financial basis of regions: the spatial structure and implications of the UK pension fund system. Regional Studies 29, 125-44

Minns, R. 1980. Pension Funds and British Capitalism: The Ownership and Control of Shareholdings. London: Macmillan

Mitchell, O.S. and Zeldes, S.P. 1996. Social security privatisation: a structure for analysis. American Economic Review, Papers and Proceedings 86 (2), 363-67

Nottage, R. and Rhodes, G. 1986. Pensions: A Plan for the Future. London: AngloGerman Foundation for the Study of Industrial Society

Paine, T. H. 1993. The changing character of pensions: where employers are headed. In Pensions in a Changing Economy edited by R. V. Burkhauser and D. Salisbury. Washington DC: Employee Benefit Research Institute, pp. 33-40

Orloff, A. S. 1993. The Politics of Pensions: A Comparative Analysis of Britain, Canada, and the United States, 1880-1940. Madison: University of Wisconsin Press

Phillips, W. 1957. Pension Scheme Precedents. London: Sweet and Maxwell 
Queisser, M. 1996. Pensions in Germany. Policy Research Working Paper 1664. Washington DC: World Bank

Reno, V. 1993. The role of pensions in retirement income. In Pensions in a Changing Economy edited by R. V. Burkhauser and D. Salisbury. Washington DC: Employee Benefit Research Institute, pp. 19-33

Rhodes, G. 1965. Public Sector Pensions. London: Allen \& Unwin

Roe, M. 1994. Strong Managers, Weak Owners: The Political Roots of American Corporate Finance. Princeton: Princeton University Press

Sass, S.A. 1997. The Promise of Private Pensions: The First Hundred Years. Cambridge MA: Harvard University Press

Sires, R. 1954. The beginnings of British legislation for old-age pensions. Journal of Economic History 14, 229-53

Skocpol, T. 1990. Protecting Soldiers and Mothers: The Political Origins of Social Policy in the United States. Cambridge MA: Harvard University Press

Smith, J.G. 1997. Full Employment: A Pledge Betrayed. London: Macmillan

Stead, F. 1909. How Old-Age Pensions Began to Be. London: Methuen

Tilove, R. 1976. Public Employee Pension Funds. New York: Columbia Univeisty Press 
Table 1: Personal Financial Assets for the United Kingdom, 1980, 1990, 1996 (Q3) in Current $£$ Billion

\begin{tabular}{lrrr}
\hline Financial Asset & 1980 & 1990 & $1996(\mathrm{Q} 3)$ \\
\hline Bank Deposits & 37.4 & 157.3 & 220.9 \\
Building Society Deposits* & 57.6 & 160.0 & 206.1 \\
Government Securities and Debt & 13.8 & 10.4 & 13.9 \\
Miscellaneous Instruments & 4.4 & 15.3 & 21.1 \\
National Savings & 12.1 & 35.6 & 60.1 \\
Notes and Coins & 8.3 & 13.6 & 18.2 \\
Overseas Investments** & 4.5 & 12.0 & 19.3 \\
Pension/Life Assurance & 106.6 & 528.0 & $1,075.8$ \\
Trade Credits (DOM) & 14.8 & 42.0 & 47.4 \\
Unit Trusts & 3.0 & 168.6 & 349.2 \\
UK Securities & 38.4 & 168.6 & 349.2 \\
Accruals Adjustments & 5.0 & 24.4 & 36.6 \\
\hline
\end{tabular}

Source: Personal Sector Balance Sheet (HMSO, London)

* Includes deposits with other financial institutions

**Includes direct investments and securities 
Table 2: US Households' Financial Assets 1980, 1990 and 1994 in current \$ Billion

\begin{tabular}{lrrr}
\hline \multicolumn{1}{c}{ Financial Asset } & 1980 & 1990 & \\
\hline Deposits & 1994 & & 3,104 \\
Credit market instruments incl. bonds) & 1,573 & 3,152 & 1,932 \\
U.S. Government securities and bonds & 461 & 1,499 & 2,358 \\
Municipal securities & 424 & 1,296 & 403 \\
Corporate and foreign bonds & 76 & 448 & 198 \\
Mortgages & 31 & 95 & 187 \\
Open-market paper & 111 & 177 & 60 \\
Mutual fund shares & 31 & 131 & 969 \\
Corporate and non corporate equities & 46 & 452 & 5,298 \\
Life insurance/pension fund reserves & 2,826 & 4,236 & 5,549 \\
Personal trusts & 1,165 & 3,864 & 656 \\
Security credit & 245 & 522 & 108 \\
Miscellaneous assets & 16 & 62 & 281 \\
\hline
\end{tabular}

Source: Board of Governors of the Federal Reserve System, Flow of Funds Accounts, March 1995 diskettes. Data are also published in the quarterly Z.1 release. 
Table 3: European Pension Fund Assets (1995)

\begin{tabular}{lrrr}
\hline Country & Popn (ml.) & Assets (US \$bill) & \%GDP \\
\hline Belgium & 10.1 & 17 & 8 \\
Denmark & 5.2 & 105 & 77 \\
Finland & 5.1 & 28 & 21 \\
France & 58.1 & 160 & 13 \\
Germany & 81.2 & 285 & 16 \\
Italy & 57.7 & - & - \\
Ireland & 3.6 & 15 & 32 \\
Netherlands & 15.4 & 380 & 124 \\
Norway & 4.3 & N/A & N/A \\
Portugal & 9.9 & 5 & 7 \\
Spain & 40.0 & N/A & N/A \\
Switzerland & 7.1 & 187 & 80 \\
United Kingdom & 58.4 & 721 & 76 \\
\hline
\end{tabular}

Source: Harrison (1995) 
Table 4: Four Large US Pension Funds (1996)

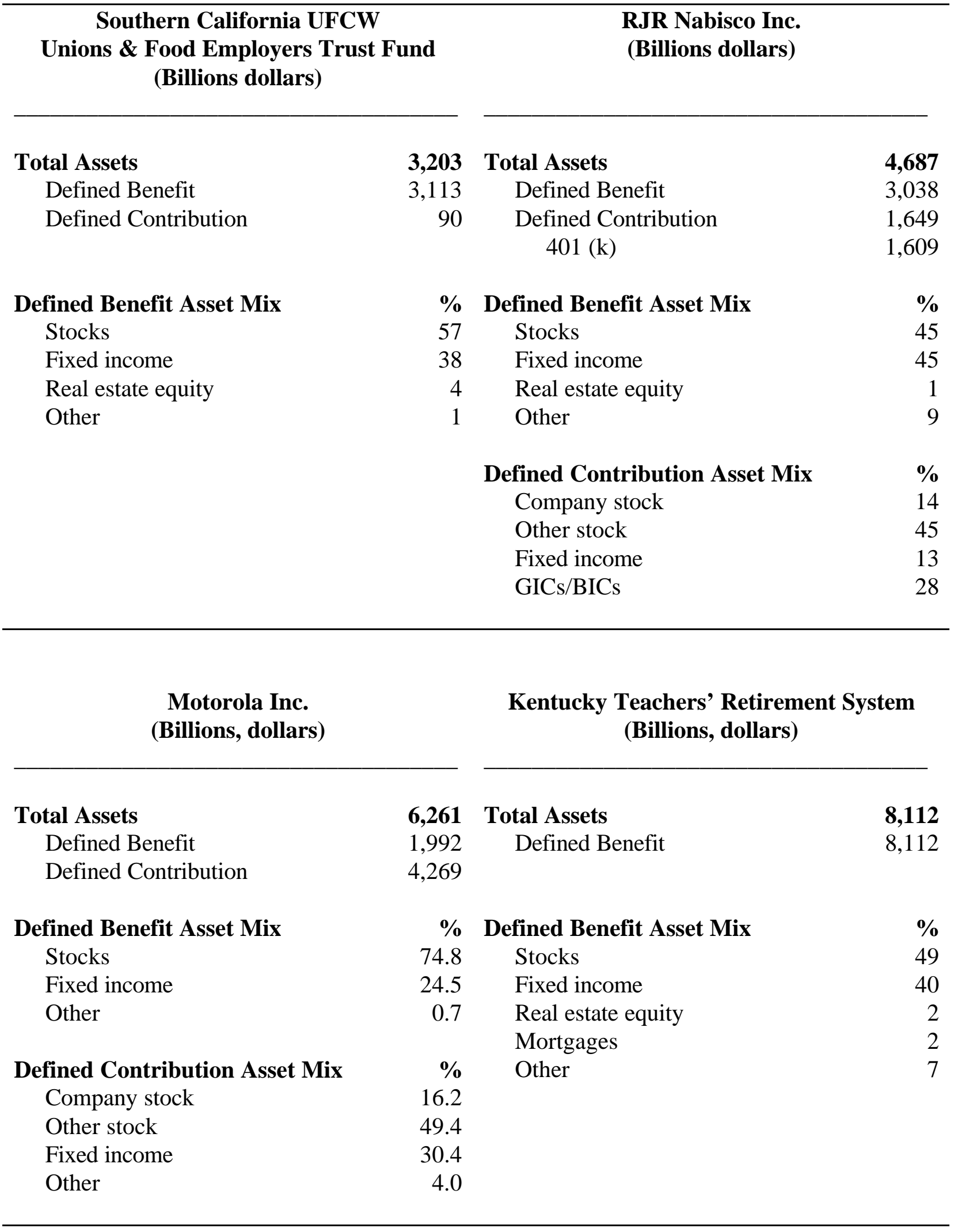

Source: Pensions \& Investments, January 20, 1997; Vol. 25 (2) 
Valdes-Prieto, S. (ed) 1997. The Economics of Pensions: Principles, Policies, and International Experience. Cambridge: Cambridge University Press

Vittas, D. 1996. Private pension funds in Hungary: early performance and regulatory issues. Policy Research Working Paper 1638. Washington DC: World Bank

Vittas, D. and Michelitsch, R. 1995. Pension funds in central Europe and Russia: their prospects and potential role in corporate governance. Policy Research Working Paper 1459. Washington DC: World Bank

\footnotetext{
i/. See also Hawley and Williams (1996) who argue that the late twentieth century is best understood as an era of "fiduciary capitalism".

ii /. Latest estimates from Deutsche Bank (1997) suggest that German, French and Italian fund assets are about 5 percent of GDP. By contrast, the value of pension fund assets for The Netherlands are estimated as (89 percent of GDP), for Switzerland as (87 percent of GDP) and for the UK as (93 percent of GDP). These data are not always as reliable as one would wish. See for comparison Davis (1995) and Harrison (1995). Davis uses a restrictive definition of pension fund assets for Germany to suggest a 1990 figure of just 3 percent of GDP whereas Harrison suggests a figure of 16 percent of GDP. Nevertheless the rank order of assets and percent of GDP is not in dispute.
}

iii /. See Vittas (1996) and Vittas and Michelitsch (1995) for a review of the current and evolving circumstances in eastern Europe.

iv $/$. I use the term "coverage rate" to refer to the proportion of workers participating in sponsored pension plans. The UK Government Actuary (1994) estimated that pension coverage is about 50 percent, having peaked in the late 1960s. This means, of course, that private pension coverage is significantly less than 50 percent (about 40 percent). In the US, the data are similar with an overall coverage rate at about 50 percent with the public pension coverage rate at around 80 percent and the private rate at around 43 percent. See the 1994 report of the US Department of Labor and compare with Reno (1993). For Germany, Queisser (1996) reports an overall coverage rate at around 46 percent for all employees. Unfortunately, the available data is somewhat unreliable.

${ }^{\mathrm{v}}$ /. According to Jones (1971) and others, there were significant differences in working class life between London and the northern industrial cities. In London, the labour market was dominated by casual employment, being driven by the comparative costs of production and the nature of demand in the local market for immediate supply. Jones (pp. 22-23) argues that employers "off-set the disadvantages of high rents, expensive fuel, high wages, and scare skills" by "sweating" the abundant supply of unskilled labour. He also argues that compared to London, northern industrial cities tended to be more amenable sites for the old, inherited customs of employer paternalism and workers' selforganisation with respect to old age and pensions.

vi /. See Stead (1909) for a detailed, personal account of the passage of the Act beginning with the early moves towards social security in the 1890s. He emphasises the role that the New Zealand social 
security legislation of 1898 had on over-turning the entrenched conservatism of the government and the Treasury (see his caustic comments on the Rothschild Report of 1898).

vii /. See, for example, Orloff (1994) comparing the political evolution of social security in Britain, Canada, and the US; Esping-Anderson (1990) on the various forms taken by the welfare state in modern capitalist economies; Skocpol (1990) on the evolution of social security pensions in the US; and Hannah (1986) on British pensions and social security.

viii /. Interestingly, there is evidence that Beveridge was influenced by Bismarck's model of social security albeit revised and crafted according to the circumstances of the mid twentieth century (see Grundger 1994). The Beveridge Report was also very influential in framing social security and employment policy in many countries immediately after the second world war. Witness the UK White Paper on Employment Policy (1944), the White Paper on Social Insurance (1944), the Australian National Welfare Fund Act of 1943 (as amended 1945), and the US Employment Act of 1946. Whether or not the promise of the Beveridge Report was ever attained is open to debate (see Smith 1997).

ix /. By the mid 1970s, however, public employee pensions had become a significant political issue in the United States and elsewhere. One major study on US state and local government employee pension funds reported that in 1967 the overall coverage rate of such employees was around 60 percent, and that in 1972 more than 8.5 million workers were involved (Tilove 1976). It was noted that union negotiations were an essential aspect of the expansion of coverage, and that benefit levels were often guaranteed by state constitutions. A latter study of the costs of public pensions by Fogelson (1984) noted that apparent rapidly rising costs of local government pensions had as much to do with the introduction of automatic cost-of-living adjustments as with the nature of work and the associated early retirement benefits enjoyed by some emergency service workers.

x/. Inland Steel v United Steelworkers of America 77 NLRB 4 (1948), 170 F.2d. 247 (7th Cir. 1949), cert. denied 336 US 960 (1949). Immediately after this decision, the federal government faced severe pressures on prices and sought to encourage unions and management to use pensions as a means of deferring negotiated wage increases (see Clark 1993 for more detail). More recently, this strategy was used in Australia as a means of managing wages and prices; see Marden and Clark (1994) on the ACCORD between unions and the previous Labor government.

${ }^{\mathrm{xi}}$ /. This observation is also relevant to the US. The recent 1994 report of the US Department of Labor observed (for the private sector) that "[c]overed workers were most likely to be employed by large firms in high wage, unionized industries" (p.8).

xii $/$. Note, however, there remains considerable unease both in the US and elsewhere about the advisability of government guarantees for private plan sponsors' pension liabilities. In the British context Roy Goode (1994a), has argued that this is a fatal flaw in ERISA, pointing to accumulated debts incurred by the PBGC. While clearly an issue, recent US data suggests that the PBGC's debts are far less than many analysts have argued in theory ought to be the case.

xiii /. See the decision of the European Court of Justice in Barber v. Guardian Royal Exchange [1990 2 CMLR 513] where the Court over-turned the British courts ruling that men and women must be treated equally in the provision of pension benefits. The Court of Justice ruled that pensions are to be treated as a form of pay and are therefore subject to equal pay principles. Craig and de Burca (1995, pp. 820-23) have a detailed treatment of this important case. Note that I do not mean to suggest that US ERISA legislation "solved" the problem of sex discrimination in the provision of pensions. A late 1970s report from the Civil Rights Division of the US department of Justice identified many unresolved issues relating to women's pension rights that would have been familiar and equally significant to the UK situation (compare with the 1976 report of the UK Occupational Pensions Board). 
${ }^{\text {xiv }}$ /. See Paine (1993) on the US situation. He reports data showing that while the number of defined contribution plans have always been larger than defined benefit plans (since 1970), only in the late 1980s did the number of participants in defined contribution plans begin to match in absolute numbers the number of participants in defined benefit plans. In essence, the growth of participants in defined contribution plans can be explained by (1) the decline in employment in large, industrial corporations with long histories of union representation, (2) the growth of smaller firms in nonindustrial sectors, and (3) the desire of many employers, large and small, to shift the burden of risk to their employees. This are issues of great significance in the UK and other Anglo-American economies.

${ }^{\mathrm{xv}}$ /. These are: Siemens (ranked 88, with US\$13.9 billion), Deutsche Bank (\#95, 13.1 billion), IBM (Germ.) (\#160, 7.1), Bayer (\#193, 5.8 billion), Hoechst (\#221, 5.1 billion), BASF (\#281, 3.9 billion), and Baugewerbe (\#282, 3.9 billion). Note that Siemens, Bayer and Hoechst are global industrial firms whose shares are widely held outside of Germany, IBM is a US firm, and Deutsche Bank is also a major global financial services firm (see Grant 1997, p. 325 on share holdings data). One could reasonably surmise that the extent to which these firms have sought Anglo-American finance they have had to conform to US and UK accounting practices that take into account unfunded pension liability.

${ }^{x v i}$ /. The Australian industry is rapidly changing. Data on the formation of new funds and the relative success of industry funds and related competitors can be found in the quarterly Bulletin of the Insurance and Superannuation Commission (AGPS, Canberra).

xvii $/$ See the comments of Keith Ambachtsheer in the September $7^{\text {th }} 1997$ issue of Pensions \& Investments comparing the operating costs of different sizes of pension plans in the US and Canadian context. Giant plans like some of the public sector plans and plans sponsored by global corporations have even greater economies of scale enabling considerable internal capacity on the investment management of pension plan assets.

xviii /. I have resisted the temptation to document in detail the asset allocation models apparent in the Anglo-American world. More details on the US can be found in Clark (1998c), Davis (1995) has a valuable international comparison, and De Ryck (1996) compares asset allocation formula in Europe. Note that with respect to Europe, there is considerable variation between countries in terms of their pension funds' asset allocations. Many countries' funds are heavily weighted towards fixed income bonds. This is particularly apparent for The Netherlands (58 percent of assets) and Switzerland (64 percent of assets).

xix /. The data presented below come from a report on market indexes by Frank Russell Co. made available through Pensions \& Investments, vol. 25 (22), p. 50; October 27, 1997.

${ }^{\mathrm{xx}}$ /. For many years, the allocation of public sector pension fund assets to equities was regulated by the federal and state and governments. In fact, there remain a number of states that limit public funds' investments in domestic equities and international equities. Reforms have been made, particularly since the opportunity costs (lost returns) of such regulations have been very high. Similar kinds of restrictions were in place in the UK, Canada and Australia until recently. Attempts to liberalise domestic and international equity allocations in continental Europe, however, have generally met with limited success. 